\title{
Premenstrual Symptom Severity, Dysmenorrhea, and School Performance in Medical Students
}

\author{
Elif Oral1 ${ }^{1}$, Tulay Sati Kirkan², Esra Yazici³ ${ }^{3}$ Mustafa Gulec ${ }^{1}$, Zeliha Cansever $^{4}$, Nazan Aydin ${ }^{5}$
}

\section{ÖZET:}

Tıp Fakültesi ög̃rencilerinde premenstrüel belirti şiddeti, dismenore ve okul performansı

Giriș: Premenstrüel sendrom özellikle genç erişkinlerde sık görülen ve işlevsellik kaybına neden olabilen önemli bir mizaç bozuklug̃udur. Biz bu çalıșmada tıp fakültesi ög̃rencilerinde adet öncesinde meydana gelen davranışsal, duygusal ve fiziksel deg̃ișiklik șiddetinin ve dismenorenin işlevsellig̃e ve özellikle de okul işlevsellig̃ine olan etkisini kesitsel olarak deg̃erlendirmeyi amaçladık.

Yöntem: Bu çalıșma Erzurum Atatürk Üniversitesi Tıp fakültesinin okumakta olan bütün sınıflardaki toplam 584 kIz ög̃renci arasından tüm sınıflardan eșit sayıda olacak șekilde rastgele seçilmiș 236 ög̃renci ile yürütüldü. Katılımcılar premenstrüel deg̃erlendirme formu ve sosyodemografik özellikleri, adet döneminin özelliklerini, diyet ve egzersiz alıșkanlıklarını ve ișlevselliḡi deg̃erlendiren çalıșmamı için hazırlanmış bir form ile deg̃erlendirildi.

Sonuçlar: Katılımcıların \%32.2 sinde $(n=76)$ premenstruel belirti yoktu, \%41.9 ( $n=99)$ hafif düzeyde, $\% 20.3(n=48)$ orta derecede ve \%5.5 ( $n=13)$ ag̃ır premenstrüel belirtilere sahipti. Karbonhidrat içeriḡi yüksek, abur cubur niteliḡinde yiyecek tüketimi yüksek premenstrüel belirti skorlarıyla ilișkiliydi ( $x=18.475, p=0.030$ ). Katılımcıların \%67'sinde dismenore vardı ve dismenore șiddetli premenstrüel belirtilerle ve düşük okul performansı ile anlamlı bir ilişkiye sahipti $(x=14.471, p=0.002)$.

Tartıșma: Premenstrüel dönemdeki davranışsal, duygusal ve fiziksel deg̃işiklikler özellikle de ag̃rılı adet görme hem devamlıık hem de sınav performansı ile deg̃erlendirilen okul performansını olumsuz etkilemektedir. Ag̃rı kontrolü ve diyet önerileri, özellikle de abur cubur nitelig̃indeki yüksek karbonhidrat içerikli, paketli gıda tüketimini azaltılması tedavide önemli yer tutabilir.

Anahtar sözcükler: premenstrüel semptomlar, dismenore, okul performansı

Journal of Mood Disorders 2012;2(4):143-52

\section{ABSTRACT:}

Premenstrual symptom severity, dysmenorrhea, and school performance in medical students

objective: Premenstrual syndrome (PMS) represents a significant public health problem for women and it is particularly common in younger age groups. This study aimed to estimate the prevalence, severity, and determinants of PMS and dysmenorrhea and their effects on school performance in medical students.

Method: In this study (performed at Ataturk University School of Medicine in Erzurum, Turkey), 236 students were randomly selected from 554 female medical students. The participants who agreed to participate in the study completed the Premenstrual Assessment Form (PAF), a sociodemographic form, and a questionnaire assessing school performance and other functionality areas.

Results: PMS symptom severity was as follows: $32.2 \%$ $(n=76)$ exhibited no symptoms, but mild, moderate, and severe symptom severity were $41.9 \%$ ( $n=99), 20.3 \%(n=48)$ and $5.5 \%(n=13)$, respectively. Higher levels of carbohydrate and junk food consumption were related with higher premenstrual symptom scores $(x=18.475, p=0.030)$. Of al participants, 67\% had dysmenorrhea, which was significantly related with severe premenstrual symptoms ( $x=14.471$, $p=0.002$ ) and poorer school performance.

Conclusions: Diet recommendations (e.g., eating less junk food and carbohydrates) could help young women by reducing symptoms. Because dysmenorrhea seems to be strongly related with severe premenstrual symptoms and poorer educational performance, treatment strategies (even those merely aimed at pain control) could help to improve the class attendance and exam performance of female medical students.

Key words: premenstrual symptoms, dysmenorrhea, school performance

Journal of Mood Disorders 2012;2(4):143-52
${ }^{1}$ M.D., Psych., Assist. Prof., Ataturk University Medical Faculty Department of Psychiatry, Erzurum-Turkey

${ }^{2}$ M.D., Psych., Research Assist., Ataturk University Medical Faculty Department of Psychiatry, Erzurum-Turkey

${ }^{3}$ M.D., Psych., Derince Training and Research Hospital, Department of Psychiatry, Kocaeli-Turkey

${ }^{4}$ M.D., Assist Prof., Ataturk University Medical Faculty Department of Medical Education,

Erzurum-Turkey

${ }^{5}$ M.D. Psych., Prof., Ataturk University Medical Faculty Department of Psychiatry, Erzurum-Turkey

Yazışma Adresi / Address reprint requests to: Elif Oral, M.D., Psych., Assist. Prof

Ataturk University Medical Faculty Department of Psychiatry, Yakutiye 25240 ,

Erzurum-Turkey

Telefon / Phone: +90-442-231-6954

Faks / Fax: +90-442-236-1301

Elektronik posta adresi / E-mail address: oralelif@yahoo.com

Kabul tarihi / Date of acceptance: 12 Eylül 2012 / September 12, 2012

\section{Bag̃ıntı beyanı}

E.O., T.S.K., E.Y., M.G., Z.C., N.A.: Yazarlar bu makale ile ilgili olarak herhangi bir cıkar catısması bildirmemiștir.

\section{Declaration of interest.}

E.O., T.S.K., E.Y., M.G., Z.C., N.A.: The authors reported no conflict of interest related to this article.

\section{INTRODUCTION}

One of the most important biological rhythms is menstruation, which occurs cyclically and reflects reproductive ability in mammals. In humans, every $28 \pm 7$ days, the endometrium desquamates as a result of hormonal changes. From menarche to menopause, women have a long reproductive lifespan (average 36 years) (1). This period includes an average of 400 menstrual cycles that may or may not cause difficulty (2). 
Up to $80 \%$ of women report one or more physical, psychological, or behavioral symptoms during the luteal phase of their menstrual cycle without experiencing substantial disruption in their daily functioning (3). Premenstrual syndrome (PMS) is a commonly used term for a group of emotional, behavioral, and physical symptoms that occur for several days before menstrual bleeding and calm during the menstrual period (4). The symptoms present a cyclic and recurrent character, which are variable in quality and intensity. A severe form of PMS is classified as premenstrual dysphoric disorder (PMDD), according to the Diagnostic and Statistical Manual of Mental Disorders, fourth edition (5). The diagnosis of PMDD requires the prospective assessment of at least two consecutive menstrual periods.

According to the International Statistical Classification of Diseases and Related Health Problems, 10th revision (ICD-10), the diagnosis of PMS requires the presence of one premenstrual symptom from a list of symptoms. These include mild psychological discomfort, feelings of bloating and weight gain, breast tenderness, swelling of the hands and feet, various aches and pains, poor concentration, sleep disturbances, and changes in appetite. These are restricted to the luteal phase of the menstrual cycle and relieved with the start of menstrual flow (6). Although there is a consensus that PMS encompasses various premenstrual symptoms, it is still unclear whether an essential number of symptoms for diagnosis exist and whether some symptoms are more important than others.

Epidemiologically, PMS occurs in $20-32 \%$ of premenopausal women; the more severe symptoms of PMDD affect about 3-8\% of premenopausal women (7). This disorder is particularly common in the younger age groups and therefore represents a significant public health problem in young women $(8,9)$. The prevalence of PMDD varies substantially across studies, likely because of the different definitions for PMDD. Initially, PMS and PMDD appeared to be limited to women in Western cultures, but more recent studies have demonstrated that symptoms suggesting PMS and PMDD occur at similar rates globally (9-12). The most common premenstrual symptoms in the Turkish population have been shown to include fatigue, anxiety, general physical disturbances, social isolation, and atypical depressive features (13). Various biological and psychological causes have been proposed as causes of PMS, including abnormal serotonin function, the absence of progesterone, altered endorphin modulation of gonadotropin secretion, lack of exercise, smoking, alcohol use, poor dietary habits, and caffeine consumption (13). Prostaglandins, the hormones that cause muscle contractions and decrease blood flow and oxygen to the uterus, are thought to be the cause of dysmenorrhea (14). About half of the adolescents and young adults experience menstrual discomfort, and consequently this condition can lead to the impairment of school or work performance $(15,16)$.

This cross-sectional study was conducted to examine the patterns of menstrual cycles and related problems, and school performance during the menstrual period in medical students. For the sake of reliability, we conducted this study on medical students, as it was assumed that they would have a greater awareness of the presence and severity of their physical, psychological, and behavioral symptoms.

\section{METHOD}

\section{Participants}

The present study was conducted at Atatürk University School of Medicine in Erzurum, Turkey. In total, 236 students were randomly selected from 554 female medical students at the university. Exclusion criteria included a) suffering from a metabolic disease or psychiatric disorder that requires treatment with psychotropic medication,b) using hormonal contraceptives, and c)using other prescribed medicines (e.g., antidepressants, antipsychotics, and mood stabilizers). The students were approached during their lecture period (after obtaining permission from both their coordinator and class teachers) and were asked to complete the questionnaire under the close supervision of the authors.

\section{Instruments}

The participants who accepted to participate in the study completed the Premenstrual Assessment Form (PAF), a sociodemographic and menstruation information form, and a questionnaire that was prepared for this study assessing school performance and other functionality areas. The sociodemographic and menstruation information form consisted of questions on a number of 
Table 1: The subscales of the PAF

\section{The subscales of PAF}

Low Mood

Endogenous Depressive Features

Instability

Atypical Depressive Features

Hysteroid Features

Hostility/Anger

Social Withdrawal

Anxiety

Organic Mental Discomfort

General Physical Discomfort

Signs of Water Retention

Autonomic Physical Changes

Fatigue

Impaired Social Functioning

Miscellaneous Behavior/Mood Changes

Miscellaneous Physical Changes

\section{Questions}

$19,22,38,48,49,51,57,66,78,89$

$8,23,40,64,82$

$1,46,47$

$1,5,27,46,80,81$

$25,37,41,47,86$

$26,50,55,56,60,67$

$23,72,74,78$

$4,7,14,44$

$3,11,12,24,31,32$

$10,53,62$

$9,58,59,62,71,75$

$13,20,29,39,40,58,84$

$2,6,15,52$

$21,33,54,72,74,76,77,79,83,92,93$

$16,17,28,34,43,45,61,63,64,69,73,87,88,90$

$18,65,70,91,94,95$

"Premenstrual Assessment Form

demographic variables, exercise levels, nutritional habits, smoking, the presence of dysmenorrhea, duration of menstruation, regularity of menstruation, age at menarche, and family history of PMS. Body Mass Index (BMI) was calculated using self-reported data on height and weight. The PAF, a retrospective self-report questionnaire, consists of 95 questions (composite scores on 18 factors) regarding changes in mood, behavior, and physical symptoms for the previous three menstrual cycles (17). Dereboy et al. (13) published the Turkish reliability and validity study of the instrument in 1994. Total PAF scores were divided into the number of questions for each participant. According to the results, symptom severity was assessed as follows: values under 1.7 were regarded as "no PMS," from 1.7 to 2.8 "mild PMS," from 2.8 to 3.7 "moderate PMS," and over 3.7 as "severe PMS." The subscales of the PAF summarized at Table 1.

Five-point Likert scale questions were used for the retrospective assessment of social, personal, and school performance based on the last two premenstrual periods. School performance was evaluated with two domains: (1) class attendance and/or concentration difficulties during class and (2) exam performance and/or exam attendance.

\section{Statistical Analysis}

Data were analyzed using the Statistical Package for the Social Sciences (SPSS) version 20. Demographic data analyses were subjected to the mean procedure for descriptive statistics. Numeric variables were analyzed using independent t-tests and one-way ANOVAs. Categorical variables were analyzed using Chi-square and Fisher's exact tests. The Chi-square test was used to compare the scales, and different severities of PMS were used. Pearson's correlation analysis was used to determine the direction (i.e., negative or positive) of the relationship between the severity of PMS symptoms and other variables.

\section{RESULTS}

The mean age of the participants was $21.49 \pm 2.3$ years, the mean age of menarche was $13.01 \pm 1.6$ years, and the mean duration of menstrual bleeding was $6.2 \pm 1.2$ days. Of all participants, $74 \%(\mathrm{n}=151)$ had a family history of PMS, and $35 \%(n=84)$ had irregular menstrual periods.

The participants' sociodemographic data are summarized in Table 2. Symptom severity levels of the participants were as follows: $32.2 \%(n=76)$ exhibited no premenstrual symptoms, while $41.9 \%$ ( $\mathrm{n}=99$ ) exhibited mild, 20.3\% ( $n=48)$ exhibited moderate, and 5.5\% $(n=13)$ exhibited severe PMS symptoms. There was no relationship between sociodemographic variables and premenstrual symptom severity except as it was related to nutritional habits (i.e., higher levels of carbohydrate and junk food consumption were related with higher premenstrual symptom scores) 
$(\mathrm{x}=18.475, \mathrm{p}=0.030)$. Although $5.2 \%$ of participants who suffered from severe PMS had regular and balanced diet habits, $12.2 \%$ of the high junk food and carbohydrate consumers suffered from severe PMS (Table 3).

Of all participants, 67\% ( $n=159)$ suffered from dysmenorrhea. In terms of menstrual features, dysmenorrhea was significantly related with severe premenstrual symptoms $(\mathrm{x}=14.471, \mathrm{p}=0.002)$. Of the participants who had severe PMS, 92\% also had dysmenorrhea. Only $7.7 \%$ of the participants with severe PMS did not also suffer from dysmenorrhea. The results indicated that PMS severity gradually increased with the presence of dysmenorrhea. Moreover, there were moderate negative correlation between most of the

\section{Table 2: Socio-demographical characteristics of the study participants}

\begin{tabular}{|c|c|c|}
\hline Socio-demographic variables & $\mathbf{n}$ & $\%$ \\
\hline \multicolumn{3}{|l|}{ Distribution according to classes } \\
\hline 1 & 36 & 15.5 \\
\hline 2 & 41 & 17.6 \\
\hline 3 & 36 & 15.3 \\
\hline 4 & 61 & 26.2 \\
\hline 5 & 28 & 12.5 \\
\hline 6 & 31 & 13.3 \\
\hline \multicolumn{3}{|l|}{ Residence } \\
\hline live with family & 73 & 30.9 \\
\hline live with housemate & 68 & 28.8 \\
\hline live in dormitory & 87 & 36.9 \\
\hline live alone & 8 & 3.4 \\
\hline \multicolumn{3}{|c|}{ Informing about menstruation before first period } \\
\hline Yes & 206 & 87.3 \\
\hline No & 30 & 12.7 \\
\hline \multicolumn{3}{|l|}{ Regularity of menstruation } \\
\hline Regular & 84 & 35.6 \\
\hline Irregular & 152 & 64.4 \\
\hline \multicolumn{3}{|l|}{ Dysmenorrhea } \\
\hline Presence & 159 & 67.4 \\
\hline Absence & 77 & 32.6 \\
\hline \multicolumn{3}{|l|}{ Physical exercise level } \\
\hline 1- 3 hour /week & 14 & 5.9 \\
\hline Less than 1 hour /week & 6 & 2.5 \\
\hline Irregular & 116 & 49.2 \\
\hline Never & 100 & 42.4 \\
\hline \multicolumn{3}{|l|}{ Nutritional habits } \\
\hline Regular and balanced diet & 96 & 40.7 \\
\hline High carbohydrate and junk foods & 49 & 20.8 \\
\hline Low carbohydrate, high vegetables & 57 & 24.2 \\
\hline Irregular & 34 & 14.4 \\
\hline \multicolumn{3}{|l|}{ Smoking } \\
\hline Life-long non smoker & 226 & 95.8 \\
\hline Cessation to smoking & 0 & 0 \\
\hline Smoker & 10 & 4.2 \\
\hline \multicolumn{3}{|l|}{ Caffeine consumption } \\
\hline$\geq 3$ cup & 144 & 61.0 \\
\hline $1-3$ cup & 84 & 35.6 \\
\hline$<1$ cup & 8 & 3.4 \\
\hline \multicolumn{3}{|l|}{ Family history of PMS } \\
\hline mother & 40 & 16.9 \\
\hline sister & 83 & 35.2 \\
\hline aunt & 22 & 9.3 \\
\hline cousin & 36 & 15.3 \\
\hline
\end{tabular}




\begin{tabular}{|c|c|c|c|c|c|c|}
\hline & $\begin{array}{c}\text { Non-PMS* } \\
\mathrm{n}=76 \\
\text { No. }(\%)\end{array}$ & $\begin{array}{c}\text { Mild-PMS } \\
\mathrm{n}=99 \\
\text { No. }(\%)\end{array}$ & $\begin{array}{l}\text { Moderate- } \\
\text { PMS } \\
\mathrm{n}=48 \\
\text { No. }(\%)\end{array}$ & $\begin{array}{l}\text { Severe- } \\
\text { PMS } \\
n=13 \\
\text { No. }(\%)\end{array}$ & Statistics & $P$ \\
\hline Age (mean \pm SD) & $21.1 \pm 2.9$ & $21.5 \pm 1.9$ & $22.0 \pm 2.3$ & $21.0 \pm 1.5$ & $f=1.743$ & 0.159 \\
\hline BMI (mean \pm SD) & $21.4 \pm 2.5$ & $21.6 \pm 2.3$ & $22.1 \pm 2.7$ & $20.6 \pm 1.9$ & $f=1.772$ & 0.153 \\
\hline $\begin{array}{l}\text { Age at menarche (years) } \\
\text { (mean } \pm \text { SD) }\end{array}$ & $12.9 \pm 1.8$ & $13.1 \pm 1.1$ & $12.9 \pm 1.2$ & $12.0 \pm 3.6$ & $\mathrm{f}=1.450$ & 0.229 \\
\hline $\begin{array}{l}\text { Duration of menstruation bleeding } \\
\text { (days) (mean } \pm \text { SD) }\end{array}$ & $6.3 \pm 1.2$ & $6.0 \pm 1.3$ & $6.4 \pm 1.1$ & $6.6 \pm 1.2$ & $f=1.982$ & 0.117 \\
\hline $\begin{array}{l}\text { Regularity of menstruation } \\
\text { Regular } \\
\text { Irregular }\end{array}$ & $\begin{array}{l}34(40.5) \\
42(27.6)\end{array}$ & $\begin{array}{l}26(31.0) \\
73(48.0)\end{array}$ & $\begin{array}{l}18(21.4) \\
30(19.7)\end{array}$ & $\begin{array}{l}6(7.1) \\
7(4.6)\end{array}$ & $\chi^{2}=7.240$ & 0.065 \\
\hline $\begin{array}{l}\text { Dysmenorrhea } \\
\text { Present } \\
\text { Absent }\end{array}$ & $\begin{array}{l}40(25.2) \\
36(46.8)\end{array}$ & $\begin{array}{l}69(43.4) \\
30(39.0)\end{array}$ & $\begin{array}{l}38(23.9) \\
10(13.0)\end{array}$ & $\begin{array}{l}12(7.5) \\
1(1.3)\end{array}$ & $\chi^{2}=14.471$ & $0.002^{*}$ \\
\hline $\begin{array}{l}\text { Physical exercise level } \\
1 \text { - } 3 \text { hour / week } \\
\text { Less than } 1 \text { hour /week } \\
\text { Irregular } \\
\text { Never }\end{array}$ & $\begin{array}{c}3(21.4) \\
0(.0) \\
32(27.6) \\
41(41.0)\end{array}$ & $\begin{array}{c}8(57.1) \\
4(66.7) \\
53(45.8) \\
34(34.0)\end{array}$ & $\begin{array}{c}3(21.4) \\
1(16.7) \\
25(21.6) \\
19(19.0)\end{array}$ & $\begin{array}{c}0(.0) \\
1(16.7) \\
6(6.4) \\
6(6.0)\end{array}$ & $\chi^{2}=11.560$ & 0.239 \\
\hline $\begin{array}{l}\text { Nutritional habits } \\
\text { Regular and balanced diet } \\
\text { High carbohydrate and junk foods } \\
\text { High vegetables } \\
\text { Irregular }\end{array}$ & $\begin{array}{l}38(39.6) \\
14(28.6) \\
14(24.6) \\
10(29.4)\end{array}$ & $\begin{array}{l}42(43.8) \\
19(38.8) \\
26(45.6) \\
12(35.3)\end{array}$ & $\begin{array}{l}11(11.5) \\
10(20.4) \\
15(26.3) \\
12(35.3)\end{array}$ & $\begin{array}{l}5(5.2) \\
6(12.2) \\
2(3.5) \\
0(.0)\end{array}$ & $\chi^{2}=18.475$ & $0.030^{*}$ \\
\hline
\end{tabular}

"Premenstrual Syndrome

subscale scores and dysmenorrheal: Low Mood ( $\mathrm{r}=-0.224$, $\mathrm{p}=0.001)$, Endogenous Depressive Features $(\mathrm{r}=-0.315$, $\mathrm{p}=0.000)$, Atypical Depressive Features $(\mathrm{r}=-0.259, \mathrm{p}=0.000)$, Hostility/Anger $(\mathrm{r}=-0.253, \mathrm{p}=0.000)$, Social Withdrawal $(\mathrm{r}=-0.235, \mathrm{p}=0.000)$, Anxiety $(\mathrm{r}=-0.261, \mathrm{p}=0.000)$, Organic Mental Discomfort ( $\mathrm{r}=-0.264, \mathrm{p}=0.000)$, General Physical Discomfort $(\mathrm{r}=-0.266, \mathrm{p}=0.000)$, Signs of Water Retention $(\mathrm{r}=-0.218, \mathrm{p}=0.001)$, Autonomic Physical Changes $(\mathrm{r}=-$ $0.304, \mathrm{p}=0.000)$, Fatigue $(\mathrm{r}=-0.273, \mathrm{p}=0.000)$, Impaired Social Functioning $(\mathrm{r}=-0.288, \mathrm{p}=0.000)$, Miscellaneous Behavior/Mood Changes $(\mathrm{r}=-0.236, \mathrm{p}=0.001)$, and Miscellaneous Physical Changes ( $\mathrm{r}=-0.338, \mathrm{p}=0.000$ ).

The data on assessment of functionalities during last two menstrual periods were shown at table 4 .

Impairments in all functionality areas, except selfcare functionality, were significantly related with severity of PMS. In particular, poorer school attendance and exam performance were related with severe premenstrual symptoms (Table 5).

Of the participants who had severe PMS, $61.5 \%$ had significantly poorer class attendance, concentration during class, and exam performance. Social functionality was seriously affected in $46.2 \%$ of dysmenorrhea sufferers and $3.9 \%$ of the participants who did not suffer from dysmenorrhea. Although academic and social functionality areas were affected by the presence of dysmenorrhea, self-care functionality appeared to be unaffected. The PAF subscale scores and their relationships with premenstrual symptom severity were summarized in Table 6.

According to the post-hoc analysis, the Atypical Depressive Features, Hostility, Increased Well-being, Impulsiveness, and General Physical Discomfort subscale scores were not related with the severity of PMS. The Anxiety and Signs of Water Retention subscale scores were related with the severity of PMS at the $\mathrm{p}<0.05$ level. All other subscale scores were related with the severity of PMS at the $\mathrm{p}<0.001$ level. The presence of dysmenorrhea was significantly correlated with poorer school performance (Tables 7 and 8 ). 
Table 4: Assessment of social, personal and school functionality during last two premenstrual periods

\begin{tabular}{lcc} 
Functionality areas & $\mathbf{n}$ & \% \\
\hline Social /Family relationships & 52 & 22.0 \\
Unaffected & 104 & 44.1 \\
Slightly affected & 47 & 19.9 \\
Moderately affected & 29 & 12.3 \\
Significantly affected & 4 & 1.7 \\
Seriously affected & & 34.7 \\
Self-care & 82 & 36.8 \\
Unaffected & 91 & 15.3 \\
Slightly affected & 36 & 8.5 \\
Moderately affected & 20 & 3.0 \\
Significantly affected & 7 & \\
Seriously affected & & 39.8 \\
School attendance & 94 & 29.7 \\
Unaffected & 70 & 12.3 \\
Slightly affected & 29 & 11.4 \\
Moderately affected & 6.8 \\
Significantly affected & 27 & \\
Seriously affected & 16 & 3.9 \\
Exam attendance and assessments of exam performance & & 14.0 \\
Unaffected & 73 & 33.9 \\
Slightly affected & 80 & 46.9 \\
Moderately affected & 33 & 4 \\
Significantly affected & & \\
Seriously affected & &
\end{tabular}

Table 5: Functionality and premenstrual symptom severity

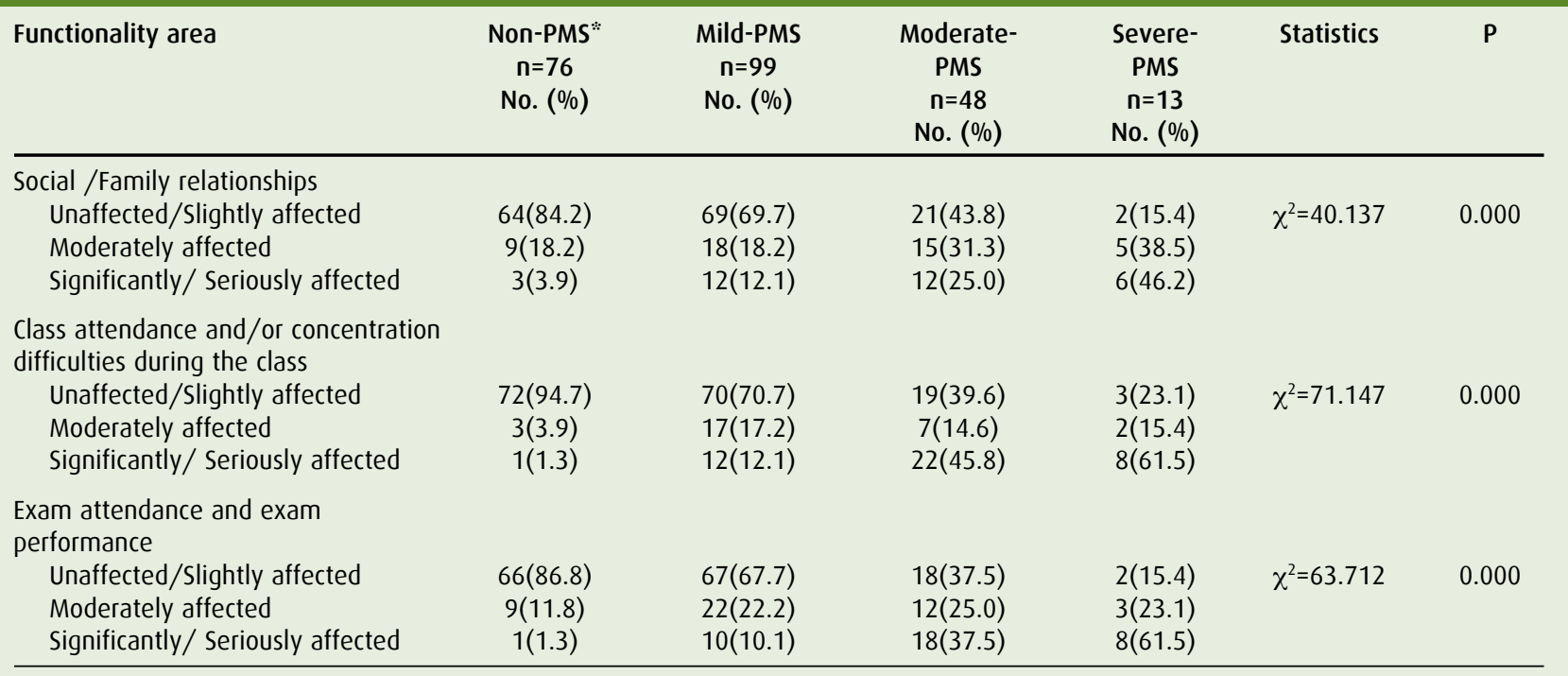

"Premenstrual Syndrome

Class attendance and/or concentration difficulties during class and exam attendance and exam performance worsened with the presence of dysmenorrhea. Of the participants who had dysmenorrhea, $94.6 \%$ had seriously impaired attendance and poor exam performance (this ratio was $5.4 \%$ in the participants who did not have dysmenorrhea). Similarly, class attendance and/or concentration difficulties were significantly affected in $93.0 \%$ of participants who had dysmenorrhea and $7.0 \%$ of the participants who did not have dysmenorrhea. 


\begin{tabular}{|c|c|c|c|c|c|c|}
\hline Subscales of PAF & $\begin{array}{c}\text { Non-PMS } \\
n=76 \\
\text { (mean } \pm S D)\end{array}$ & $\begin{array}{c}\text { Mild-PMS } \\
\quad \mathrm{n}=99 \\
(\mathrm{mean} \pm S D)\end{array}$ & $\begin{array}{c}\text { Moderate- } \\
\text { PMS } \\
n=48 \\
\text { (mean } \pm \text { SD) }\end{array}$ & $\begin{array}{c}\text { Severe- } \\
\text { PMS } \\
n=13 \\
\text { (mean } \pm S D \text { ) }\end{array}$ & Statistics & $\mathbf{P}$ \\
\hline Low mood & $13.7 \pm 3.37$ & $23.03 \pm 6.92$ & $36.6 \pm 7.37$ & $44.6 \pm 6.29$ & $f=191.99$ & 0.000 \\
\hline Endogenous Depressive Features & $6.81 \pm 1.80$ & $10.13 \pm 2.67$ & $15.79 \pm 4.38$ & $22.23 \pm 3.63$ & $f=159.51$ & 0.000 \\
\hline Instability & $4.97 \pm 1.85$ & $8.34 \pm 2.74$ & $12.22 \pm 2.73$ & $15.07 \pm 2.81$ & $f=116.39$ & 0.000 \\
\hline Atypical Depressive Features & $11.76 \pm 3.87$ & $18.21 \pm 4.48$ & $25.54 \pm 4.04$ & $28.15 \pm 3.13$ & $f=136.41$ & 0.000 \\
\hline Hysteroid Features & $6.14 \pm 1.39$ & $10.98 \pm 3.27$ & $16.54 \pm 4.66$ & $20.38 \pm 3.54$ & $\mathrm{f}=144.03$ & 0.000 \\
\hline Hostility/Anger & $11.76 \pm 3.87$ & $18.21 \pm 4.48$ & $25.54 \pm 4.04$ & $28.15 \pm 3.13$ & $f=136.41$ & 0.000 \\
\hline Social Withdrawal & $5.84 \pm 1.87$ & $9.41 \pm 3.23$ & $14.64 \pm 4.73$ & $21.30 \pm 3.01$ & $f=127.51$ & 0.000 \\
\hline Anxiety & $6.80 \pm 2.14$ & $10.91 \pm 2.96$ & $16.20 \pm 3.12$ & $18.30 \pm 2.42$ & $f=148.53$ & 0.000 \\
\hline Increased Well-being & $4.78 \pm 1.32$ & $5.93 \pm 2.32$ & $7.47 \pm 3.69$ & $8.15 \pm 5.08$ & $f=13.29$ & 0.000 \\
\hline Impulsiveness & $4.94 \pm 1.20$ & $7.88 \pm 3.28$ & $12.12 \pm 4.10$ & $13.84 \pm 2.57$ & $f=74.52$ & 0.000 \\
\hline Organic Mental Discomfort & $7.69 \pm 2.02$ & $12.21 \pm 4.05$ & $18.43 \pm 5.72$ & $23.92 \pm 5.36$ & $f=104.51$ & 0.000 \\
\hline General Physical Discomfort & $5.26 \pm 2.08$ & $7.72 \pm 2.55$ & $11.83 \pm 3.85$ & $13.46 \pm 2.14$ & $f=75.16$ & 0.000 \\
\hline Sign of water retention & $9.48 \pm 2.80$ & $14.54 \pm 4.64$ & $20.08 \pm 5.23$ & $23.46 \pm 3.95$ & $f=82.28$ & 0.000 \\
\hline Autonomic Physical Changes & $9.55 \pm 2.28$ & $13.13 \pm 3.68$ & $19.68 \pm 4.15$ & $27.61 \pm 4.23$ & $f=155.64$ & 0.000 \\
\hline Fatigue & $7.61 \pm 3.11$ & $11.86 \pm 3.37$ & $17.66 \pm 3.72$ & $20.92 \pm 2.56$ & $f=120.74$ & 0.000 \\
\hline Impaired Social Functioning & $13.60 \pm 2.77$ & $22.87 \pm 5.57$ & $36.56 \pm 8.18$ & $51.07 \pm 5.86$ & $f=273.69$ & 0.000 \\
\hline Miscellaneous Behavior/mood & $16.48 \pm 2.57$ & $24.45 \pm 4.65$ & $33.95 \pm 5.98$ & $44.84 \pm 4.29$ & $\mathrm{f}=248.06$ & 0.000 \\
\hline Miscellaneous Physical changes & $8.80 \pm 2.19$ & $11.95 \pm 3.23$ & $16.75 \pm 4.43$ & $20.38 \pm 3.27$ & $f=86.83$ & 0.000 \\
\hline
\end{tabular}

"Premenstrual Syndrome

Table 7: Association between dysmenorrhea and exam attendance and exam performance

\begin{tabular}{|c|c|c|c|c|}
\hline & \multicolumn{2}{|c|}{ Dysmenorrhea } & \multirow[b]{2}{*}{$\chi^{2}$} & \multirow[b]{2}{*}{$\mathbf{p}$} \\
\hline & $\begin{array}{c}\text { Presence } \\
n=159 \\
\text { No. }(\%)\end{array}$ & $\begin{array}{c}\text { Absence } \\
n=77 \\
\text { No. }(\%)\end{array}$ & & \\
\hline \multicolumn{5}{|c|}{ Exam attendance and exam performance } \\
\hline Unaffected/Slightly affected & $84(54.9)$ & $69(45.1)$ & 31.324 & 0.000 \\
\hline Moderately affected & $40(87.0)$ & $6(13.0)$ & & \\
\hline Significantly/ Seriously affected & $35(94.6)$ & $2(5.4)$ & & \\
\hline
\end{tabular}

Table 8: Association between dysmenorrhea and class attendance and/or concentration difficulties during the class

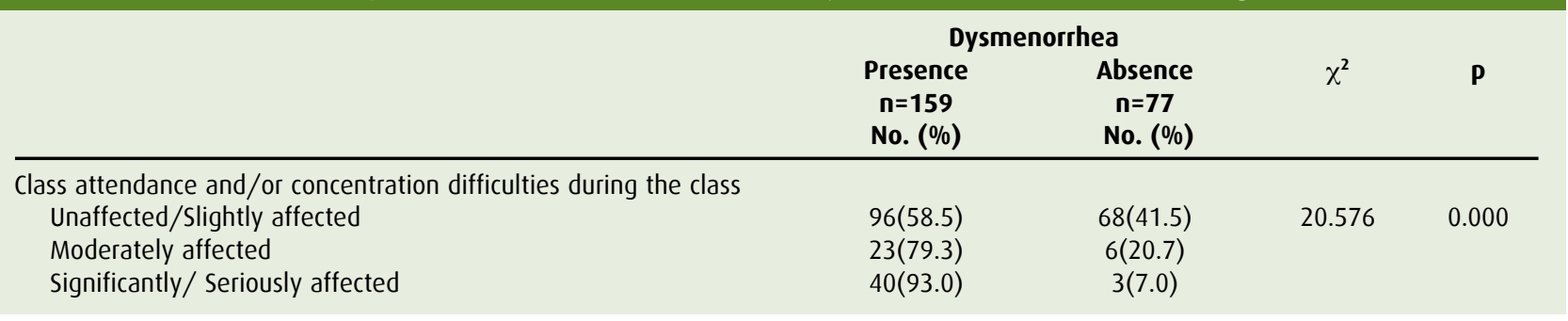

\section{DISCUSSION}

In this study, $32.2 \%(\mathrm{n}=76)$ of the participants exhibited no premenstrual symptoms, while $41.9 \%(\mathrm{n}=99)$ exhibited mild, 20.3\% ( $n=48)$ exhibited moderate, and 5.5\% $(n=13)$ exhibited severe PMS symptoms. The rate of severe PMS has been reported as between $4.9 \%$ and $16.2 \%$ (18). In a study conducted with 310 Australian women aged 18-45, the rate of severe PMS was found to be $11 \%$ (19). In another study conducted with 21-35-year-old women, it was found that $8 \%$ of the women had severe, and $14 \%$ had moderate PMS (20). Dereboy et al. found prevalence rates 
of $10 \%$ and $27 \%$ for severe and moderate PMS, respectively, in Turkish university students (13). Nisar et al. reported that $59.5 \%$ of medical students in Pakistan had mild, $29.2 \%$ had moderate, and $11.2 \%$ had severe PMS (21). The variability of PMS severity in the literature may be due to the fact that the studies were conducted with different age groups and populations with different sociocultural backgrounds.

Of the participants in the current study, 67\% $(n=159)$ had dysmenorrhea, which was significantly related with severe premenstrual symptoms and higher scores on almost all PAF subscales. Although some studies have reported no relation between dysmenorrhea and PMS $(22,23)$, a positive relationship has been reported in most of the studies conducted with young adults (24-26) and adolescents (27-29). Steiner et al. also reported that the prevalence of dysmenorrhea was high, particularly in those with severe PMS or PMDD; the prevalence of dysmenorrhea was $63.7 \%$ in those with no/mild PMS, $81.7 \%$ in those with severe PMS, and $73.8 \%$ in adolescents with PMDD (30). Similar results were found in our study. Biochemical changes in severe PMS and dysmenorrhea may correspond with each other, and reduced prostaglandin levels may relieve both of them. Moreover, the treatment of dysmenorrhea may help to reduce premenstrual symptoms and related difficulties in school performance in young women.

According to our results, higher level of carbohydrate and junk food consumption was related to higher premenstrual symptom scores, although the relationship between dysmenorrhea and nutritional habits was not significant. Studies have shown significant reductions in menstrual pain and premenstrual symptoms with increased fruit and vegetable intake (31-33). Diet habits related with the high consumption of vegetables may be related with lower levels of estradiol, which may lead to the reduced premenstrual symptomatology.

Recent studies have shown that there is a relation between coffee consumption and the severity of PMS (27, 34 ), as caffeine is a stimulant and increases stress, irritability, and emotionality (35). In one study, it was shown that the frequency of PMS increases with the amount of caffeine consumption, but the finding was not statistically significant. In this study, no relationship between caffeine consumption and the severity of PMS was found (36).
In our study, BMI was normal in $76.3 \%$, low in $11.0 \%$, and high in $11.9 \%$ of the participants, and two of the participants $(0.8 \%)$ were overweight. There was no significant relationship between BMI and premenstrual symptoms. However, in other studies, the PMS rate has been demonstrated to increase as BMI rises (34, 36-38).

Although some researchers have not been able to show a significant relationship between PMS frequency and impaired quality of life (36), PMS, which is very common in the community, affects female adolescents' family relationships, social lives, business affairs, productivity, self-confidence, course attendance, success, and life quality (39). A relationship between severe premenstrual symptoms and impaired life quality in young adults has been demonstrated (40). We reviewed studies on the effects of premenstrual symptoms on educational performance, especially in medical schools, and found that more severe premenstrual symptoms are related with a reduction in educational performance (21). Issa et al. reported that scores of an impairment in general health questionnaire were not significantly related with the presence of PMDD (41). Balaha et al. reported that the more frequent limitations in severe PMS were related to activities such as concentration in class, college attendance, going out of the home, daily chores, and homework tasks (42). In this study, impairment in all functionality areas was significantly correlated with higher PAF scores. In particular, poorer school attendance and exam performance were related with severe premenstrual symptomatology more than self-care functionality. The presence of dysmenorrhea was significantly correlated with poorer school performance, including class attendance and/or concentration difficulties during class and exam performance/exam attendance. This is significant, as academic performance is an important performance domain that may affect other areas of functionality.

Regarding limitations of the present study, first, our participants were randomly selected from one medical school, making it difficult to generalize the results. Second, we used a retrospective self-rating scale for assessing premenstrual symptomatology, and we assessed school and general performance using fivepoint Likert scales, as we assumed that using an instrument that was brief and required less effort would encourage participation. 


\section{CONCLUSIONS}

Premenstrual symptoms are one of the most common problem area among young women that adversely affect their academic performance and emotional status, so strategies should be developed for early detection and management of PMS in young women. Students should receive professional support in order to overcome the problems associated with PMS. Relieving the problems of young people suffering from PMS and the coping strategies

\section{References:}

1. Harlow SD. Menstruation and menstrual disorders: The epidemiology of menstruation and menstrual dysfunction. In Women and Health, Goldman M, Hatch M (editors). San Diego, CA: Academic Press, 2000: 99-113.

2. Chiou MH, Wang HH, Yang YH. Effect of systematic menstrual health education on dysmenorrheic female adolescents' knowledge, attitudes, and self-care behavior. Kaohsiung J Med Sci. 2007;23:183-90.

3. O'Brien PM, Eriksson E. Premenstrual syndrome. Lancet. 2008;371:1200-10

4. Silva CM, Gigante DP, Carret ML, Fassa AG. Population study of premenstrual syndrome. Rev Saude Publica. 2006;40:47-56.

5. American Psychiatric Association. Diagnostic and Statistical Manual of Mental Disorders, fourth edition (DSM-IV), 1994.

6. World Health Organization (WHO). International Statistical Classification of Diseases and Related Health Problems. 10th Revision (ICD -10). Geneva: WHO, 1992.

7. Rapkin AJ, Winer SA. Premenstrual syndrome and premenstrual dysphoric disorder: Quality of life and burden of illness. Expert Rev Pharmacoecon Outcomes Res. 2009;9:157-70.

8. Halbreich U. The diagnosis of premenstrual syndromes and premenstrual dysphoric disorder clinical procedures and research perspectives. Gynecol Endocrinol. 2004;19:320-34.

9. Derman O, Kanbur NO, Tokur TE, Kutluk T. Premenstrual syndrome and associated symptoms in adolescent girls. Eur J Obstet Gynecol Reprod Biol. 2004;116:201-6.

10. Adewuya AO, Loto OM, Adewumi TA. Pattern and correlates of premenstrual symptomatology amongst Nigerian university students. J Psychosom Obstet Gynaecol. 2009;30:127-32.

11. Nisar N, Zehra N, Haider G, Munir AA, Sohoo NA. Frequency, intensity and impact of premenstrual syndrome in medical students. J Coll Physicians Surg Pak. 2008;18:481-4.

12. Lee AM, So-Kum Tang C, Chong C. A culturally sensitive study of premenstrual and menstrual symptoms among Chinese women. J Psychosom Obstet Gynaecol. 2009;30:105-14.

13. Dereboy C, Dereboy IF, Yigitol F. Psychometric data for the Premenstrual Assessment Form: A cluster analytic study. Turk Psikiyatri Derg. 1994;5:83-90. are expected to assist in the elimination of such problems. Students should be informed by medical staff about PMS and coping strategies. Even simple recommendations about diet regulation (e.g., eating less junkfood and carbohydrates) may help young women to reduce symptoms. Because dysmenorrhea seems to be strongly related with severe premenstrual symptoms and poorer educational performance, treatment strategies (even those merely aimed at pain control) could help to improve the class attendance and exam performance of female medical students.

14. Campbell MA, McGrath PJ. Non-pharmacologic strategies used by adolescents for the management of menstrual discomfort. Clin J Pain. 1999;15:313-20.

15. Klein JR, Litt IF. Epidemiology of adolescent dysmenorrhea Pediatrics. 1981;68:661-4

16. Andersch B, Milsom I. An epidemiological study of young women with dysmenorrhea. Am J Obstet Gynecol. 1982;144:655-60.

17. Halbreich U, Endicott J, Schacht S. Premenstrual syndromes: A new instrument for their assessment. J Psychiatr Treat Eval. 1982;4:161-4.

18. Halbreich U, Borenstein J, Pearlstein T, Kahn LS. The prevalence, impairment, impact, and burden of premenstrual dysphoric disorder (PMS/PMDD). Psychoneuroendocrinology. 2003;28:1-23.

19. Campbell EM, Peterkin D, O'Grady K, Sanson-Fisher R. Premenstrual symptoms in general practice patients. Prevalence and treatment. J Reprod Med. 1997;42:637-46.

20. Freeman EW. Premenstrual syndrome and premenstrual dysphoric disorder: Definitions and diagnosis. Psychoneuroendocrinology. 2003;28:25-37.

21. Nisar N, Zehra N, Haider G, Munir AA, Sohoo NA. Frequency, intensity and impact of premenstrual syndrome in medical students. J Coll Physicians Surg Pak. 2008;18:481-4.

22. Rupani NP, Lema VM. Premenstrual tension among nurses in Nairobi, Kenya. East Afr Med J. 1993;70:310-3.

23. Freeman EW, Rizcksels K, Sondheimer SJ. Premenstrual symptoms and dysmenorrhea in relation to emotional distress factors in adolescents. J Psychosom Obstet Gynecol. 1993;14:41-50.

24. Indusekhar R, Usman BS, O'Brien S. Psychological aspects of premenstrual syndrome. Best Pract Res Clin Obstet Gynecol. 2007;21:207-20.

25. Aksu H, Sokullu G. Premenstrual syndrome and its effects on daily life. J Arch Lit Rev. 2008;17:111-9.

26. Perkonigg A, Yonkers KA, Pfister H, Lieb R, Wittchen HU. Risk factors for premenstrual dysphoric disorder in a community sample of young women: The role of traumatic events and posttraumatic stress disorder. J Clin Psychiatry. 2004;65:1314-22. 
27. Gunes G, Pehlivan E, Genc M, Egri M. Frequency of premenstrua syndrome of high school students in Malatya. J Turgut Özal Med Center 1997;4:403-6.

28. Erenel SA, Senturk I. Health high school students experienced dysmenorrhoea and their applications to cope with it. Hacettepe Univ Faculty of Health Sciences Nursing Journal. 2007;14:48-60.

29. Derman O, Kanbur NO, Tokur TE, Kutluk T. Premenstrual syndrome and associated symptoms in adolescent girls. Eur J Obstet Gynecol Reprod Biol. 2004;116:201-6.

30. Steiner M, Peer M, Palova E, Freeman EW, Macdougall M, Soares CN. The Premenstrual Symptoms Screening Tool revised for Adolescents (PSST-A): Prevalence of severe PMS and premenstrual dysphoric disorder in adolescents. Arch Women's Ment Health. 2011;14:77-81.

31. Balbi C, Musone R, Menditto A, Di Prisco L, Cassese E, D’Ajello M, Ambrosio D, Cardone A. Influence of menstrual factors and dietary habits on menstrual pain in adolescence. Eur J Obstet Gynecol Reprod Biol. 2000;91:143-8.

32. Barnard ND, Scialli AR, Hurlock D, Bertron P. Diet and sex hormone binding globulin, dysmenorrhea, and premenstrual symptoms. Obstet Gynecol. 2000;95:245-50.

33. Tavallaee M, Joffres MR, Corber SJ, Bayanzadeh M, Rad MM. The prevalence of menstrual pain and associated risk factors among Iranian women. J Obstet Gynaecol Res. 2011;37:442-51.

34. Deuster PA, Adera T, South-Paul J. Biological, social and behavioral factors associated with premenstrual syndrome. Arch Fam Med. 1999;8:122-8.
35. Musal B, Ucku R, Aksakoglu G, Blaban C. Determination of premenstrual symptoms in married women in the age group of 15-49 in the Narlidere region. New Opin Develop Gynecol Obstet. 1992;3:61-4.

36. Demir B, Algul LY, Guven ESG. Analysis of premenstrual syndrome incidence in medical staff and factors affecting premenstrual syndrome incidence. J Turkish Gynaecol Obstet Found. 2006;3:26270 .

37. Ince N. Premenstrual syndrome in adolescence. Clin Med Sci (Turkey). 2001;21:369-73.

38. Pinar A. Frequency of premenstrual syndrome in women in the age group of 15-49. Unpublished postgraduate thesis, Institute of Medical Sciences, Akdeniz University, Antalya; 2007.

39. Tasc1 DK. Assessment of premenstrual symptoms of nursing students. TSK Prevent Med Bull. 2006;5:434-42.

40. Lustyk MK, Widman L, Paschane A, Ecker E. Stress, quality of life and physical activity in women with varying degrees of premenstrual symptomatology. Women Health. 2004;39:35-44.

41. Issa BA, Yussuf AD, Olatinwo AW, Ighodalo M. Premenstrual dysphoric disorder among medical students of a Nigerian university. Ann Afr Med. 2010;9:118-22.

42. Balaha MH, Amr MA, Saleh Al Moghannum M, Saab Al Muhaidab $\mathrm{N}$. The phenomenology of premenstrual syndrome in female medical students: A cross sectional study. Pan Afr Med J. 2010;5:4. 